\title{
Effect of Foliar Application of Micronutrients on Fruit Quality of Peach
}

\author{
Amjad Ali ${ }^{*}$, Sajida Perveen², Syed Noor Muhammad Shah ${ }^{3,4}$, Zengqiang Zhang1, \\ Fazli Wahid $^{2}$, Mohib Shah' ${ }^{5}$, Shahida Bibi', Abdul Majid7 \\ ${ }^{1}$ College of Natural Resources and Environment, Northwest A\&F University, Yangling, China \\ ${ }^{2}$ Soil and Environmental Sciences, University of Agriculture, Peshawar, Pakistan \\ ${ }^{3}$ Department of Horticulture, Faculty of Agriculture, Gomal University, D. I. Khan, Pakistan \\ ${ }^{4}$ College of Horticulture, Northwest A\&F University, Yangling, China \\ ${ }^{5}$ Department of Botany, Abdul Wali Khan University, Mardan, Pakistan \\ ${ }^{6}$ Department of Weed Science, University of Agriculture, Peshawar, Pakistan \\ ${ }^{7}$ Department of Agriculture Chemistry, Faculty of Agriculture, Gomal University, D.I. Khan, Pakistan \\ Email: amjadali@aup.edu.pk
}

Received 8 February 2014; revised 11 March 2014; accepted 23 March 2014

Copyright (C) 2014 by authors and Scientific Research Publishing Inc.

This work is licensed under the Creative Commons Attribution International License (CC BY).

http://creativecommons.org/licenses/by/4.0/

(c) (i) Open Access

\section{Abstract}

This experiment was conducted to study the effect of foliar spray of micronutrients on quality of peach fruits at Horticulture Farm, University of Agriculture Peshawar during 2010. The experiment was conducted in randomized complete design with six treatments and four replications on peach orchards (early grand). Our pre-treatment soil analysis showed silt loam soil class, alkaline and calcareous in nature and adequate in organic matter. The soil was deficient in $\mathrm{P}, \mathrm{Zn}, \mathrm{Fe}$ and $\mathrm{B}$, whereas adequate in $\mathrm{Mn}$ and $\mathrm{Cu}$. The fruit quality was evaluated and maximum fruit length, diameter and yield were noted in $\mathrm{T}_{6}(\mathrm{Zn}+\mathrm{Cu}+\mathrm{Fe}+\mathrm{Mn}+\mathrm{B})$. The juice $\mathrm{pH}$ decreased and the juice acidity increased in a linear fashion after foliar spray of micronutrients. The total soluble solids of fresh fruit juice ranged $7.01 \%-8.88 \%$ and vitamin $C$ ranged from $4.80 \%-7.90 \%$ after foliar spray. So the foliar spray of micronutrients significantly $(P \leq 0.05)$ affected the quality of peach fruit.

\section{Keywords}

Acidity; Fruit Quality; Micronutrients; Peach; Spray; Vitamin C

\section{Introduction}

Peach (Prunus persical L.) belongs to the family Rosaceae with other species collectively known as “stone fruits”.

"Corresponding author. 
Important varieties grown worldwide are Cling and Free Stone. Peshawar and Swat are best suited for Early Grand, Florida King 6-A and 7, 8, 9 peach cultivars. The soil and climatic conditions of Khyber Pakhtunkhwa are suitable for the production of peach. According to Agricultural Statistics of Pakistan [1], peach orchards covered 15.8 thousand ha area in Pakistan, producing 83.7 thousand tons of peach fruit, while in Khyber Pakhtunkhwa it covers an area of 6.2 thousand hectares producing 57.8 thousand tons of peaches. The main sources of micronutrients are parent material, sewage sludge, town refuse, fungicides and farmyard manure and are present in small amount in soil [2]. Micronutrients play a key role in plants growth and productivity [3]. Zinc is a component of almost 60 enzymes; it has a role in producing the growth hormone IAA. Zinc plays a key role in $\mathrm{N}$ metabolism of plant and Zn deficient plants have reduced protein content [4] [5]. Copper is essential for the growth of plant and helps in the formation of vitamin A [6]. Symptoms of copper deficiency include abnormal and stunted leaf development, stunted shoot growth with dieback, reduced flowering and fruit set, and small fruit with poor color and quality [7]. Iron forms important enzymes and is associated with chlorophyll synthesis. Iron deficient peach trees have small size, resulting in a large decrease in acceptable fruits [8]. Iron chlorosis reduces fruit production, reducing the number of fruits per tree, fruit size, fruit yield and affecting fruit quality parameters such as firmness and acidity. Fe fertilization increases fruit quality and yield in many crops [9]. Manganese is involved in photosynthesis, metabolism of nitrogen and carbohydrate. Boron is helpful in plant growth and productivity. It increases the germination of pollen grains and elongation of pollen tube, fruit setting and yield in orchards [10]. Boron is responsible for activation of dehydrogenase enzymes, sugar translocation, nucleic acids and plant hormones [11]. There are many soil and climatic factors affecting the availability of micronutrients to plants. The major factors include: $\mathrm{pH}$, soil water content, organic matter, interaction among the nutrients and temperature. The availability of $\mathrm{B}$ and AB-DTPA extractable $\mathrm{Zn}, \mathrm{Cu}, \mathrm{Fe}$ and $\mathrm{Mn}$ decreases with increasing soil $\mathrm{pH}$ [12] [13]. Study shows the deficiency of $\mathrm{Zn}(17 \%), \mathrm{Cu}(13 \%), \mathrm{Fe}$ (45\%), Mn (2\%) and B (95\%) in orchards. The soils are alkaline, non-saline, calcareous and low in organic matter in Peshawar Valley [14]. These micronutrients are more soluble in the acidic $\mathrm{pH}$ and their availability in soils varies considerably with the seasonal changes in temperature and moisture [15]. As peach trees are deep rooted so foliar application of micronutrients is a valuable tool for fighting against the micronutrient deficiencies. Curing micronutrient deficiencies through foliar application is a common practice in getting profitable yield and good quality fruit [16]. Foliar spray of micronutrients is advantageous over soil application, because of rapid response, effectiveness and elimination of deficiency symptoms due to certain micronutrients. Results indicated that spraying the trees twice or thrice is more effective than spraying once a year in improving micronutrients content of peach trees [10]. This study was aimed to study the effect of micronutrients (Zn, Cu, Fe, Mn and B) spray on fruit set, yield and fruit quality of peach orchards.

\section{Materials and Methods}

Experimental Design and Fertilizers: The experiment was conducted on peach orchards at University of Agriculture, Peshawar-Pakistan during 2010 (February-June).Twenty four trees were selected for this purpose. Six treatments with four replications were applied. A basal dose of $150 \mathrm{~kg} \mathrm{~N} \mathrm{ha}^{-1}, 100 \mathrm{~kg} \mathrm{P}_{2} \mathrm{O}_{5} \mathrm{ha}^{-1}$ and $100 \mathrm{~kg} \mathrm{~K}_{2} \mathrm{O}$ $\mathrm{ha}^{-1}$ as Urea, SSP and SOP was applied. The micronutrients $\mathrm{Zn}, \mathrm{Cu}, \mathrm{Fe}, \mathrm{Mn}, \mathrm{B}$ at rate of 5, 2.5, 5, 5, $1 \mathrm{Kg} \mathrm{ha}^{-1}$ respectively were applied in split dose. The detail of the micronutrients doses and their combinations is given in Table 1. Before incorporation of basal dose of fertilizers, composite soil sample was taken for the determination of various physico-chemical characteristics. After foliar spray the fruit length $(\mathrm{cm})$, diameter $(\mathrm{cm})$, No. of fruits tree $^{-1}$, yield tree ${ }^{-1}$, fruit volume, Juice $\mathrm{pH}$, Juice acidity, Total Soluble Solids and Vitamin C were recorded.

Soil Analysis: Soil samples were analyzed for soil texture [17], pH [18], EC [19], organic matter [20], lime [21], extractable micronutrients, P and K [22] and B in leaf and soil [23].

Fruit Analysis: The fruit analysis was performed at edible maturity stage. Physical properties were measured by Maurer and Taylor method [24]. The chemical properties of fruit were determined according to the methods of AOAC [25].

Statistical Analysis: Data were subjected to analysis of variance and differences among treatments were evaluated [26] [27].

\section{Results and Discussions}

Physico-chemical characteristics of experimental soil: The Physico-chemical characteristics of soil are presented in Table 2. The soil was silt loam, $\mathrm{pH}$ ranged from 7.73 - 7.96, which was low in the surface and increased linearly with depth. The differences might be due to leaching of bases from the surface and its accumu- 
Table 1. Micronutrient treatments used for foliar spray on peach orchard.

\begin{tabular}{cc}
\hline Treatments & Foliar spray of various micronutrients \\
\hline$T_{1}$ & $\begin{array}{c}\text { Control } \\
\mathrm{T}_{2}\left(5 \mathrm{Kg} \mathrm{ha}^{-1}\right)\end{array}$ \\
$\mathrm{T}_{3}$ & $\mathrm{Zn}+\mathrm{Cu}\left(5 \mathrm{Kg} \mathrm{ha}^{-1}+2.5 \mathrm{Kg} \mathrm{ha}^{-1}\right)$ \\
$\mathrm{T}_{4}$ & $\mathrm{Zn}+\mathrm{Cu}+\mathrm{Fe}\left(5 \mathrm{Kg} \mathrm{h}^{-1}+2.5 \mathrm{Kg} \mathrm{ha}^{-1}+5 \mathrm{Kg} \mathrm{ha}^{-1}\right)$ \\
$\mathrm{T}_{5}$ & $\mathrm{Zn}+\mathrm{Cu}+\mathrm{Fe}+\mathrm{Mn}\left(5 \mathrm{Kg} \mathrm{ha}^{-1}+2.5 \mathrm{Kg} \mathrm{ha}^{-1}+5 \mathrm{Kg} \mathrm{ha}^{-1}+5 \mathrm{Kg} \mathrm{ha}^{-1}\right)$ \\
$\mathrm{T}_{6}$ & $\mathrm{Zn}+\mathrm{Cu}+\mathrm{Fe}+\mathrm{Mn}+\mathrm{B}\left(5 \mathrm{Kg} \mathrm{ha}^{-1}+2.5 \mathrm{Kg} \mathrm{ha}^{-1}+5 \mathrm{Kg} \mathrm{ha}^{-1}+5 \mathrm{Kg} \mathrm{ha}^{-1}+1 \mathrm{Kg} \mathrm{ha}^{-1}\right)$ \\
\hline
\end{tabular}

Table 2. Physico-Chemical Characteristics of Experimental Soil.

\begin{tabular}{|c|c|c|c|c|c|}
\hline Properties of soil & Unit & $0-15 \mathrm{~cm}$ & $15-30 \mathrm{~cm}$ & $30-45 \mathrm{~cm}$ & $45-60 \mathrm{~cm}$ \\
\hline $\mathrm{pH}_{(1: 5)}$ & - & 7.73 & 7.89 & 7.93 & 7.96 \\
\hline $\mathrm{EC}_{(1: 5)}$ & $\mathrm{dS} \mathrm{m}^{-1}$ & 0.20 & 0.20 & 0.17 & 0.16 \\
\hline Soil Organic Matter (\%) & $\%$ & 2.07 & 1.93 & 1.86 & 1.83 \\
\hline Lime (\%) & $\%$ & 20.75 & 19.25 & 17.50 & 17 \\
\hline AB-DTPA extractable P & $\mathrm{mg} \mathrm{Kg}{ }^{-1}$ & 6.47 & 6.28 & 5.52 & 5.39 \\
\hline AB-DTPA extractable K & $\mathrm{mg} \mathrm{Kg}{ }^{-1}$ & 100 & 100 & 50 & 50 \\
\hline AB-DTPA extractable Zn & $\mu \mathrm{g} \mathrm{g}^{-1}$ & 1.14 & 1.00 & 0.57 & 0.56 \\
\hline AB-DTPA extractable $\mathrm{Cu}$ & $\mu \mathrm{g} \mathrm{g}^{-1}$ & 5.38 & 5.30 & 3.29 & 2.52 \\
\hline AB-DTPA extractable Fe & $\mu g^{-1}$ & 3.76 & 3.28 & 2.45 & 2.29 \\
\hline AB-DTPA extractable Mn & $\mu \mathrm{g} \mathrm{g}^{-1}$ & 19.16 & 18.67 & 17.50 & 14.50 \\
\hline Dilute $\mathrm{HCl}$ available B & $\mu \mathrm{g} \mathrm{g}^{-1}$ & 0.45 & 0.29 & 0.32 & 0.37 \\
\hline Soil Texture & Silt loam & & & & \\
\hline
\end{tabular}

lation in subsurface. The $\mathrm{pH}$ of Peshawar soil is generally alkaline [12]. The EC of the suspension varied from $0.16-0.20 \mathrm{dS} \mathrm{m}^{-1}$. The results showed that the soil organic matter ranged $1.83 \%-2.07 \%$ (marginal-adequate). The soil is calcareous due to the high $\mathrm{CaCO}_{3}$ content in the parent material [12]. The extractable P ranged 5.39 $6.47 \mathrm{mg} \mathrm{Kg}^{-1}$. Data showed that extractable P was marginal. The K concentration in the surface $(0-30 \mathrm{~cm})$ soil was marginal and low in the subsoil $(30-60 \mathrm{~cm})$.

Micronutrients content in soil of peach orchards: The data regarding the AB-DTPA extractable micronutrients is presented in Table 2. The $\mathrm{Zn}$ content ranged $0.56-1.14 \mu \mathrm{g} \mathrm{g}^{-1}$. The concentration ranged from low $\left(<0.9 \mu \mathrm{g} \mathrm{g}^{-1}\right)$ to marginal $\left(0.9-1.5 \mu \mathrm{g} \mathrm{g}^{-1}\right)$ in soil. About $70 \%$ of the cultivated soils in Pakistan are deficient in $\mathrm{Zn}$ [28]. The $\mathrm{Cu}$ content was high $\left(>0.5 \mu \mathrm{g} \mathrm{g}^{-1}\right)$ in soil samples collected from four depths. The Fe content ranged low $\left(<3.0 \mu \mathrm{g} \mathrm{g}^{-1}\right)$ to marginal $\left(3.0-5.0 \mu \mathrm{g} \mathrm{g}^{-1}\right.$ ) levels. The Mn content ranged 14.50 to $19.16 \mu \mathrm{g} \mathrm{g}$ which was high $\left(>1.0 \mu \mathrm{g} \mathrm{g}^{-1}\right)$ in all the depths. The soil of Khyber Pakhtunkhwa is adequate in Mn content as reported by Khattak and Perveen (1985). The acid soluble B ranged $0.37-0.45 \mu \mathrm{g} \mathrm{g}^{-1}$. The concentration of B was low $\left(<0.45 \mu \mathrm{g} \mathrm{g}^{-1}\right)$. Khattak and Perveen [29] reported 98\% deficiency of B in soils of Khyber Pakhtunkhwa.

\section{Fruit Quality}

\subsection{Physical Properties of Fruit}

1) Fruit Length (cm): Fruit length was significantly $(P \leq 0.05)$ influenced by micronutrients spray (Table 3$)$. Maximum fruit length $(6.41 \mathrm{~cm})$ was noted in $\mathrm{T}_{6}(\mathrm{Zn}+\mathrm{Cu}+\mathrm{Fe}+\mathrm{Mn}+\mathrm{B})$, followed by $\mathrm{T}_{5}(\mathrm{Zn}+\mathrm{Cu}+\mathrm{Fe}+\mathrm{Mn})$ and $\mathrm{T}_{4}(\mathrm{Zn}+\mathrm{Cu}+\mathrm{Fe})$ whereas significantly short fruits $(5.64 \mathrm{~cm})$ were noted in control and Zn applied plants. These results were found in harmony with the work of Baloch [30] and Ramezaniand Shekafandeh [31].

2) Fruit Diameter (cm): Fruit diameter was significantly $(\mathrm{P} \leq 0.05)$ increased by micronutrients spray (Table 3$)$. Larger and healthy fruits $(5.83 \mathrm{~cm})$ were noted in $\mathrm{T}_{6}(\mathrm{Zn}+\mathrm{Cu}+\mathrm{Fe}+\mathrm{Mn}+\mathrm{B})$ whereas, the poor were found in $\mathrm{T}_{1}$ (control). Moreover, $\mathrm{T}_{2}$ is similar to $\mathrm{T}_{3}$. The increase in fruit diameter was linear from $\mathrm{T}_{1}$ to $\mathrm{T}_{6}$. The same trend was reported by Shahin et al. [32] and Ramezani and Shekafandeh [31] while working on plum and olive fruit, respectively.

3) Number of Fruit per Tree: The results significantly $(\mathrm{P} \leq 0.05)$ varied when different treatments of foliar 
spray were applied (Table 3). Moreover, maximum number of fruits (615) were obtained in $\mathrm{T}_{6}(\mathrm{Zn}+\mathrm{Cu}+\mathrm{Fe}+$ $\mathrm{Mn}+\mathrm{B})$, followed by $\mathrm{T}_{5}(\mathrm{Zn}+\mathrm{Cu}+\mathrm{Fe}+\mathrm{Mn})$ with a fruit number of 585 followed by $\mathrm{T}_{4}(\mathrm{Zn}+\mathrm{Cu}+\mathrm{Fe})$, while $\mathrm{T}_{1}$ (control) gave minimum (448) number of fruits. Same results were reported by Shahin et al. [32] and Hassan et al. [4].

4) Fruit Yield (Kg/tree): Fruit yield was significantly $(\mathrm{P} \leq 0.05)$ increased by micronutrients spray (Table 3$)$. The higher yield (64.54 Kg/tree) was obtained in case of $\mathrm{T}_{6}(\mathrm{Zn}+\mathrm{Cu}+\mathrm{Fe}+\mathrm{Mn}+\mathrm{B})$. The results regarding $\mathrm{T}_{2}$ $(\mathrm{Zn}), \mathrm{T}_{3}(\mathrm{Zn}+\mathrm{Cu}), \mathrm{T}_{4}(\mathrm{Zn}+\mathrm{Cu}+\mathrm{Fe})$ and $\mathrm{T}_{5}(\mathrm{Zn}+\mathrm{Cu}+\mathrm{Fe}+\mathrm{Mn})$ were statistically comparable but better than the control (untreated) where minimum yield (40.62 Kg/tree) was obtained. These results were found in harmony with the work of Nasiriet al. [33], Ibrahim et al. [34] and Khayyat et al. [35], where micronutrients were applied to citrus and date palm, which increased the yield in a linear fashion.

5) Fruit Volume $\left(\mathbf{c m}^{3}\right)$ : The results showed significant $(P \leq 0.05)$ increase in fruit volume (Table 3$)$. The maximum fruit volume $\left(267.51 \mathrm{~cm}^{3}\right)$ was obtained in $\mathrm{T}_{6}(\mathrm{Zn}+\mathrm{Cu}+\mathrm{Fe}+\mathrm{Mn}+\mathrm{B})$ followed by $\mathrm{T}_{5}(\mathrm{Zn}+\mathrm{Cu}+\mathrm{Fe}$ $+\mathrm{Mn})$ and $\mathrm{T}_{4}(\mathrm{Zn}+\mathrm{Cu}+\mathrm{Fe})$. The poor fruit volume $\left(195.01 \mathrm{~cm}^{3}\right)$ was noted in $\mathrm{T}_{1}$ (control). The increase in fruit volume is due to availability of applied nutrients.

\subsection{Chemical Properties of Fruits}

1) Juice pH: It can be seen from the results that the application of foliar spray significantly $(P \leq 0.05)$ decreased the juice $\mathrm{pH}$ (Table 4). It was noted that higher juice $\mathrm{pH}$ (3.86) was reported in $\mathrm{T}_{1}$ (control) followed by $\mathrm{T}_{2}$ (Zn only), while the lower juice $\mathrm{pH}$ was noted in $\mathrm{T}_{6}$, where all the micronutrients were applied. These findings were in line with the work of Tariq et al. [14].

2) Juice Acidity (\%): The results showed that foliar spray significantly $(\mathrm{P} \leq 0.05)$ increased juice acidity over control (Table 4$)$. It was noted that the maximum juice acidity $(0.39 \%)$ was reported in plants sprayed with $\mathrm{T}_{6}$ followed by $\mathrm{T}_{5}$ and $\mathrm{T}_{4}$. The minimum juice acidity $(0.24 \%)$ was noted in control.

3) Total Soluble Solids (TSS): It can be seen from the results that the application of foliar spray significantly $(\mathrm{P} \leq 0.05)$ increased the total soluble solids (Table 4). It was noted that significantly $(\mathrm{P} \leq 0.05)$ higher total soluble solids (8.87\%) were reported in $\mathrm{T}_{6}$ followed by $\mathrm{T}_{5}$ and $\mathrm{T}_{4}$. The lower total soluble solids were noted in $\mathrm{T}_{1}$ (control).

4) Vitamin $\mathbf{C}(\mathbf{m g} / \mathbf{1 0 0 m L})$ : It can be seen from the results that the foliar spray significantly $(P \leq 0.05)$ increased

Table 3. Effect of foliar spray of micronutrients on the physical properties of fruit.

\begin{tabular}{|c|c|c|c|c|c|}
\hline Treatments & Length $(\mathrm{cm})$ & Diameter (cm) & No. of fruit/tree & Fruit Yield Kg tree $^{-1}$ & Volume $\mathrm{cm}^{3}$ \\
\hline Control $\left(\mathrm{T}_{1}\right)$ & $5.64 \mathrm{c}$ & $5.19 \mathrm{~d}$ & $488 \mathrm{e}$ & $40.62 \mathrm{c}$ & $195.01 \mathrm{f}$ \\
\hline $\operatorname{Zn}\left(\mathrm{T}_{2}\right)$ & $5.71 \mathrm{c}$ & $5.41 \mathrm{c}$ & $525 \mathrm{~d}$ & $52.57 \mathrm{~b}$ & 206.26 e \\
\hline $\mathrm{Zn}+\mathrm{Cu}\left(\mathrm{T}_{3}\right)$ & $6.01 \mathrm{~b}$ & $5.48 \mathrm{c}$ & $541 \mathrm{~cd}$ & $51.66 \mathrm{~b}$ & $222.51 \mathrm{~d}$ \\
\hline $\mathrm{Zn}+\mathrm{Cu}+\mathrm{Fe}\left(\mathrm{T}_{4}\right)$ & $6.07 \mathrm{~b}$ & 5.57 bc & 557 c & $52.89 \mathrm{~b}$ & 236.26 c \\
\hline $\mathrm{Zn}+\mathrm{Cu}+\mathrm{Fe}+\mathrm{Mn}\left(\mathrm{T}_{5}\right)$ & $6.22 \mathrm{ab}$ & $5.68 \mathrm{ab}$ & $585 \mathrm{~b}$ & $51.80 \mathrm{~b}$ & 248.76 b \\
\hline $\mathrm{Zn}+\mathrm{Cu}+\mathrm{Fe}+\mathrm{Mn}+\mathrm{B}\left(\mathrm{T}_{6}\right)$ & $6.41 \mathrm{a}$ & $5.83 \mathrm{a}$ & 615 a & $64.54 \mathrm{a}$ & $267.51 \mathrm{a}$ \\
\hline $\operatorname{LSD}(\mathrm{P} \leq 0.05)$ & 0.23 & 0.19 & 20.23 & 9.09 & 9.95 \\
\hline$\% \mathrm{CV}$ & 2.48 & 2.20 & 2.45 & 11.53 & 2.89 \\
\hline
\end{tabular}

${ }^{*}$ Means are different significantly in columns at $\mathrm{P} \leq 0.05$.

Table 4. Effect of foliar spray of micronutrients on the chemical properties of the fruits.

\begin{tabular}{|c|c|c|c|c|}
\hline Treatments & Juice $\mathrm{pH}$ & J. acidity \% & TSS \% & Vitamin C \% \\
\hline Control $\left(\mathrm{T}_{1}\right)$ & 3.86 a & $0.24 \mathrm{~d}$ & $7.01 \mathrm{e}$ & $4.80 \mathrm{f}$ \\
\hline $\mathrm{Zn}\left(\mathrm{T}_{2}\right)$ & $3.78 \mathrm{a}$ & $0.25 \mathrm{~cd}$ & 7.26 de & $5.39 \mathrm{e}$ \\
\hline $\mathrm{Zn}+\mathrm{Cu}\left(\mathrm{T}_{3}\right)$ & $3.70 \mathrm{a}$ & $0.28 \mathrm{bc}$ & $7.58 \mathrm{~cd}$ & $5.91 \mathrm{~d}$ \\
\hline $\mathrm{Zn}+\mathrm{Cu}+\mathrm{Fe}\left(\mathrm{T}_{4}\right)$ & $3.70 \mathrm{a}$ & $0.29 \mathrm{~b}$ & 8.01 bc & $6.62 \mathrm{c}$ \\
\hline $\mathrm{Zn}+\mathrm{Cu}+\mathrm{Fe}+\mathrm{Mn}\left(\mathrm{T}_{5}\right)$ & $3.68 \mathrm{a}$ & $0.31 \mathrm{~b}$ & $8.36 \mathrm{~b}$ & $7.14 \mathrm{~b}$ \\
\hline $\mathrm{Zn}+\mathrm{Cu}+\mathrm{Fe}+\mathrm{Mn}+\mathrm{B}\left(\mathrm{T}_{6}\right)$ & $3.31 \mathrm{~b}$ & $0.39 \mathrm{a}$ & 8.88 a & $7.90 \mathrm{a}$ \\
\hline $\operatorname{LSD}(\mathrm{P} \leq 0.05)$ & 0.33 & 0.04 & 0.43 & 0.46 \\
\hline$\% \mathrm{CV}$ & 5.97 & 8.27 & 3.65 & 4.83 \\
\hline
\end{tabular}

\footnotetext{
${ }^{*}$ Means are different significantly in columns at $\mathrm{P} \leq 0.05$.
} 
the vitamin C content in peach fruit (Table 4). It was noted that the maximum vitamin C (7.90 mg/100mL) content was reported in $T_{6}$, where all the micronutrients were applied. The minimum vitamin $C(4.80 \mathrm{mg} / 100 \mathrm{~mL})$ content was reported in $\mathrm{T}_{1}$ (control) where no spray was applied. These results revealed that foliar spray of micronutrients has a positive effect on vitamin C content. Hassan et al. [4] reported similar findings by applying micronutrients to plum orchards.

\section{Conclusion}

The obtained results in the present research proved that foliar application of micronutrients (Zn, Cu, Fe, Mn and B) alone and in combination were the most effective treatments in increasing chemical and physical parameters of peach fruit. To increase fruit length $(\mathrm{cm})$, diameter $(\mathrm{cm})$, no. of fruit/tree, fruit yield $(\mathrm{kg} / \mathrm{tree})$, volume $\left(\mathrm{cm}^{3}\right)$, juice (pH), juice acidity (\%), TSS (\%) and vitamin C (\%) under silt loam, calcareous and alkaline condition of Peshawar soil, it is recommended to apply foliar spray twice a year to the orchards in order to enhance the efficiency of micronutrients and avoid losses by leaching and interaction among the nutrients.

\section{Acknowledgements}

We are thankful to Professor Dr. Sajida Perveen and Professor Dr. M. Jamal Khan Khattak, Department of Soil and Environmental Sciences, University of Agriculture, Peshawar, for their kind supervision and help in designing and executing the experiment. We are also thankful to the Department of Soil and Environmental Sciences, University of Agriculture, Peshawar for providing lab and research facilities.

\section{References}

[1] Pakistan, G. (2009) Agriculture Statistics of Pakistan 2008-09. Ministry of Food and Agriculture, Economic Wing, Islamabad.

[2] Nafees, M., Jan, M.R., Khan, H., Rashid, N. and Khan, F.U. (2009) Soil Contamination in Swat Valley Caused by Cadmium and Copper. Sarhad Journal of Agriculture, 25, 37-43.

[3] Bansal, O.P. (1992) Changes in Micronutrients (Cu, Zn, Mn, Ni and Cd) Concentration in Soil Amended with Sludge. Clay Research, 2, 29-32.

[4] Hassan, H.S.A., Sarrwy, S.M.A. and Mostafa, E.A.M. (2010) Effect of Foliar Spraying with Liquid Organic Fertilizer, Some Micronutrients and Gibberellins on Leaf Minerals Content, Fruit Set, Yield, and Fruit Quality of "Hollywood" Plum Trees. Agriculture and Biology Journal of North America, 1, 638-643.

[5] Mengel, K., Kosegarten, H., Kirkby, E.A. and Appel, T. (2001) Principles of Plant Nutrition. Springer, New York. http://dx.doi.org/10.1007/978-94-010-1009-2

[6] Martens, D.C. and Westermann, D.T. (1991) Fertilizer Application for Correcting Micronutrient Deficiencies. Micronutrients in Agriculture, Soil Science Society of America, Madison, 549-592.

[7] Stiles, W. C. and Reid, W.S. (1991) Orchard Nutrition Management. Cornell Cooperative Extension Information Bulletin, 219, 22.

[8] Powell, J.C., Lyons, C.G. and Haby, V.A. (1995) Effects of Copper, Zinc, and Sulfur Application to Peach Trees on Coastal Plain Soil. Communications in Soil Science \& Plant Analysis, 26, 1637-1648. http://dx.doi.org/10.1080/00103629509369396

[9] Àlvarez-Fernàndez, A., Abadía, J. and Abadía, A. (2006) Iron Deficiency, Fruit Yield and Fruit Quality. Iron Nutrition in Plants and Rhizospheric Microorganisms, Springer Netherlands, 85-101.

[10] El-Sheikh, M.H., Khafgy, S.A.A., and Zaied, S.S. (2007) Effect of Foliar Application with Some Micronutyrients on Leaf Mineral Content, Yield and Fruit Quality of "Florida Prince Desert Red” Peach Trees. Journal of Agricultural and Biological Science, 3, 309-315.

[11] Brady, N.C. and Weil, R.R. (1996) The Nature and Properties of Soils. Prentice Hall Inc., New Jersey.

[12] Rashid, M., Bhatti, A.U., Khan, F.U. and Wasiullah (2008) Physico-Chemical Properties and Fertility Status of Soils of District Peshawar and Charsadda. Soil and Environment, 27, 228-235.

[13] Khattak, J.K., Sharif, M. and Naz, S. (1994) Nutrient Status of Citrus Orchard Soils in Peshawar Valley [Pakistan]. Sarhad Journal of Agriculture, 10, 451-460.

[14] Tariq, M., Shah, Z. and Ali, A. (2008) Micronutrients Status of Plum Orchards in Peshawar Valley. Soil and Environment, 27, 223-227.

[15] Hodgson, J.F. (1963) Chemistry of the Micronutrient Elements in Soils. In: Norman, A.G., Ed., Advances in Agronomy, 
Academic Press, Salt Lake City, 119-159.

[16] Waheed, U.R. (1992) Effect of Foliar Application of Micronutrients in Combination with Urea on Yield and Fruit Quality of Sweet Oranges. M.Sc. (Hons) NWFP, Agriculture University Peshawar, Pakistan.

[17] Bouyoucos, G.J. (1962) Hydrometer Method Improved for Making Particle Size Analyses of Soils. Agronomy Journal, 54, 464-465. http://dx.doi.org/10.2134/agronj1962.00021962005400050028x

[18] Mclean, E.O. (1982) Soil pH and Lime Requirement. In: Page, A.L., Ed., Methods of Soil Analysis. Part 2. Chemical and Microbiological Properties, American Society of Agronomy, Soil Science Society of America, 199-224.

[19] Richards, L.A. (1954) Diagnosis and Improvement of Saline and Alkali Soils. Soil Science, 78, 154. http://dx.doi.org/10.1097/00010694-195408000-00012

[20] Nelson, D.W. and Sommers, L.E. (1996) Total Carbon, Organic Carbon, and Organic Matter. In: Sparks, D. L., Helmke, P.A., Loeppert, R.H., Soltanpour, P.N., Tabatabai, M.A., Johnston, C. and Sumner, M.E., Eds., Methods of Soil Analysis, Soil Science Society of America Inc., Madison, 961-1010.

[21] Page, A.L. (1982) Methods of Soil Analysis. Part 2. Chemical and Microbiological Properties. American Society of Agronomy, Soil Science Society of America, Madison.

[22] Soltanpour, P.N. and Schwab, A.P. (1977) A New Soil Test for Simultaneous Extraction of Macro- and Micro- Nutrients in Alkaline Soils 1. Communications in Soil Science \& Plant Analysis, 8, 195-207. http://dx.doi.org/10.1080/00103627709366714

[23] Bingham, F.T. (1982) Boron. In: Page, A.L., Ed., Methods of soil Analysis Part-2 Chemical and Mineralogical Properties, American Society of Agronomy, Madison, 431-448.

[24] Maurer, M.A. and Taylor, K.C. (1999) Effect of Foliar Boron Sprays on Yield and Fruit Quality of Navel Oranges. Cooperative Extension and Agricultural Experiment Station, University of Arizona, College of Agriculture.

[25] AOAC (1990) Official Methods of Analysis of the AOAC. In: Helrich, K.C., Ed., Official Methods of Analysis of the AOAC, Association of Official Analytical Chemists Inc., Arlington, 1298.

[26] STATISTIX (2000) STATISTIX7 User’s Manual. Analytical Software, Tallahassee.

[27] Scientific, J. (1991) Table Curve V. 3.0. User’s Manual Version 3.0 AISN software. Jandel Scientific, Corte Madera.

[28] Rashid, A. (1996) Secondary and Micronutrients. In: Bantel, E.S., Ed., Soil Science, National Book Foundation, Islamabad, 341-386.

[29] Khattak, J.K. and Parveen, S. (1985,) Cooperative Research Programme on Micronutrient Status of Pakistan Soils. NWFP Agricultural University Peshawar, Pakistan, 52.

[30] Baloch, Q.B., Chachar, Q.I. and Tareen, M.N. (2008) Effect of Foliar Application of Macro and Micro Nutrients on Production of Green Chilies (Capsicum annuum L.). Journal of Agriculture Technolgy, 4, 177-184.

[31] Ramezani, S. and Shekafandeh, A. (2009) Roles of Gibberellic Acid and Zinc Sulphate in Increasing Size and Weight of Olive Fruit. African Journal of Biotechnology, 8, 6791-6794.

[32] Shahin, M.F.M., Fawzi, M.I.F. and Kandil, E.A. (2010) Influence of Foliar Application of Some Nutrient (Fertifol Misr) and Gibberellic Acid on Fruit Set, Yield, Fruit Quality and Leaf Composition of “Anna” Apple Trees Grown in Sandy Soil. Journal of American Science, 6, 202-208.

[33] Nasiri, Y., Zehtab-Salmasi, S., Nasrullahzadeh, S., Najafi, N. and Ghassemi-Golezani, K. (2010) Effects of Foliar Application of Micronutrients (Fe and Zn) on Flower Yield and Essential Oil of Chamomile (Matricaria chamomilla L.). Journal of Medicinal Plant Research, 4, 1733-1737.

[34] Ibrahim, M., Ahmad, N., Anwar, S. A. and Majeed, T. (2007) Boron Nutrition and Boron Application in Crops. In: Xu, F., Goldbach, H.E., Brown, P.H., Bell, R.W., Fujiwara, T., Hunt, C.D., Goldberg, S. and Shi, L., Ed., Advances in Plant and Animal Boron Nutrition, Springer Netherlands, 179-182.

[35] Khayyat, M., Tafazoli, E., Eshghi, S., and Rajaee, S. (2007) Effect of Nitrogen, Boron, Potassium and Zinc Sprays on Yield and Fruit Quality of Date Palm. American-Eurasian Journal of Agricultural \& Environmental Sciences, 2, 289296. 


\section{Abbreviation}

AB-DTPA: Ammonium Bicarbonate Diethylene Triamine Pentaacetic Acid

AOAC: Association of Official Analytical Chemists

B: Boron

$\mathrm{CaCO}_{3}$ : Calcium Carbonate

$\mathrm{Cu}$ : Copper

ECe: Electrical Conductivity in Extract

Fe: Iron

IAA: Indole Acetic Acid

$\mathrm{K}$ : Potassium

LSD: Least Significant Difference

$\mathrm{Mn}$ : Manganese

$\mathrm{N}$ : Nitrogen

P: Phosphorus

SOP: Sulphate of Potash

SSP: Single Super Phosphate

TSS: Total Soluble Solid

Zn: Zinc 